\title{
Meningkatkan Hasil Belajar Siswa pada Materi Pengukuran melalui Metode The Power of Two and Four di SD Katolik Habi Nusa Tenggara Timur
}

\author{
Selestina Vinsensia \\ Guru di SD Katolik Habi, Sikka, Nusa Tenggara Timur \\ Email: selestina.vinsensia@ gmail.com \\ DOI : 10.32672/jsa.v7i5.1531
}

\begin{abstract}
ABSTRAK
Penelitian ini adalah penelitian tindakan kelas (Classroom Action Research) yang bertujuan untuk mengetahui pembelajaran pada mata pelajaran Matematika materi pengukuran waktu. Subyek penelitian adalah peserta didik kelas II SD Katolik Habi.Metode pengumpulan data dilakukan melalui dokumentasi, observasi dan tes. Prosedur kerja dalam penelitian ini adalah merupakan siklus kegiatan yang terdiri dari dua siklus. Dimana tiap-tiap siklus melalui tahapan - tahapan yang harus ditempuh yaitu perencanaan, pelaksanaan tindakan, observasi, refleksi. Kriteria ketuntasan adalah sebesar 70 dimana hasil belajar peserta didik dikatakan tuntas apabila memenuhi kriteria tersebut. Hasil penelitian pada tahap pra siklus rata-rata sebesar 61,66 dengan persentase 58,33\% Ini berarti kurang memenuhi kriteria. Pada siklus I memperoleh rata-rata sebesar 72,5 dengan persentase 83,33\%. Pada siklus I ini sudah memenuhi KKM tetapi kenyataan yang ada masih ada beberapa peserta didik yang masih belum tuntas sehingga perlu diadakannya siklus berikutnya. Pada siklus yang ke II adalah memperoleh nilai rata - rata sebesar 85 dengan persentase 91,66\%. Artinya penelitian pada tahap ini sudah cukup sempurna karena semua peserta didik sudah memenuhi KKM. Dengan penelitian ini diharapkan akan menjadi bahan informasi dan inovasi bagi pihak sekolah, para siswa dan para pendidik agar dapat meningkatkan hasil belajar dengan menggunakan strategi pembelajaran the power of twoand four.
\end{abstract}

Kata Kunci : The Power of Two and Four, Hasil Belajar, Peserta Didik

\section{PENDAHULUAN}

Pada dasarnya pembelajaran di kelas menuntut guru dan peserta didik untuk selalu bekerja sama dalam upaya mencapai kompetensi yang dicita-citakan. Dalam pembelajaran, peserta didik dibantu oleh guru sebagai fasilitator dalam melibatkan diri untuk membentuk kompetensi,serta mengembangkan dan memodifikasi kegiatan pembelajaran, apabila kegiatan itu menuntut adanya pengembanganan modifikasi. Kegiatan inti pembelajaran atau pembentukan kompetensi perlu dilakukan dengan tenang dan menyenangkan, hal tersebut tentu saja menuntut aktivitas dan kreativitas guru dalam menciptakan lingkungan yang kondusif.

Hal tersebut merupakan tantangan bagi pelaku pendidikan khususnya guru mata pelajaran Matematika. Untuk itu harus dicari sebab akibatnya demi tercapainya tujuan pengajaran sekaligus meningkatkan hasil belajar peserta didik. Dan salah satu upaya yang 


\section{Selestina Vinsensia}

dapat ditempuh adalah menerapkan metode pembelajaran The Power of Two and Four. Dalam kerangka esensial pembelajaran mengacu pada standar kompetensi dan kompetensi dasar, perhatian utama guru adalah bagaimana mengembangkan aspek penguasaan peserta didik meliputi aspek belajar. Hal ini merupakan upaya untukmenghasilkan manusia yang berkembang penalarannya, berpendidikan dan berwawasan luas, sehingga mampu menghadapi masalah yang dihadapi dengan bijaksana. Dengan berpegang pada konsep pembelajaran dalam proses pendidikan maka diharapkan setiappeserta didik maupun guru dapat senantiasa belajar dan menemukan sendiri maupun atas bantuan orang lain. Dibutuhkan beragam metode pembelajaran yang dapat membantu meningkatkan pemahaman dan hasil belajarpeserta didik.

Kenyataannya, dalam penyelenggaraan pendidikan ditemukan beberapa masalah yang kompleks yang pemecahannya tidak cukup dengan sains, tetapi juga secara filosofis. Seperti pembelajaran di kelas terkadang dijumpai gejala yang tidak seimbang, dimana seorang guru sekedar menyampaikan bahan mengajar tanpa dilandasi dengan kesadaran ingin memahamkan kepada peserta didik. Sehingga peserta didik kurang respek dan tidak merespon dengan baik.

Pelaksanaan metode The Power of Two and Four, sebelumnya peserta didik harus memiliki pengetahuan awalmenjadi dasar pengetahuan pesertadidik yang akan didiskusikan dalam kelas, tugas guru dalam metode The Power of Two and Four di kelas sangatlah penting dimana guru harus berperan sebagai pengamat, sebagai model, melakukan evaluasi dan melakukan perencanaan. Guru mempunyaiperanan yang sangat penting dalam proses kegiatan belajarmengajar karena guru merupakan elemen terpenting dalamsebuah sistem pembelajaran. Keberhasilan peserta didik dalam proses belajar mengajar terletak pada kreativitas pada guru pada saat pembelajaran berlangsung. Seperti memberi perhatian, dan sportif diyakini bisa memberi motivasi, yang gilirannya akan meningkatkan prestasi peserta didik. Dalam proses pembelajaran, apabila peserta didik tidak mempunyai motivasi kemungkinan besar tidak akan melakukan aktivitas belajar dengan baik. Guru tidak hanya berfungsi sebagai pengelola kelas, sebagai motivator, guru perlu memberikan rangsangan dan dorongan agar peserta didik tekun dalam belajar.

Mata pelajaran matematika, merupakan mata pelajaran yang sulit bagi sebagian besar peserta didik kelas II SD Katolik Habi. Hal ini dapat diketahui dari hasil ulangan harian peserta didik yang masih rendah. Selain itu dalam melaksanakan kegiatan belajar mengajar guru bisanya hanya menggunakan metode ceramah dan tanya jawab saja, hal ini dapat menyebabkan suasana belajar menjadi kurang menyenangkan sehingga minat dan motivasi peserta didik dalam belajar berkurang. Berdasarkan permasalahan ini, maka peneliti tertarik untuk melakukan penelitian untuk menemukan solusi dan pemecahannya.

\section{METODE PENELITIAN}

Penelitian ini merupakan jenis Penelitian Tindakan Kelas (PTK). Subjek dalam penelitian tindakan kelas ini adalah peserta didik kelas II SD Katolik Habi Tahun Pelajaran 2018 / 2019 yang berjumlah 12 peserta didik, dengan perincian peserta didik laki - laki sebanyak 3 orang dan peserta didik perempuan sebanyak 9 orang. 


\section{Siklus Penelitian}

Penelitian ini merupakan Penelitian Tindakan Kelas (PTK) yang terdiri atas beberapa siklus. Masing-masing siklus terdiri atas empat tahapan yaitu perencanaan, pelaksanaan, pengamatan dan refleksi.

PTK adalah jenis penelitian yang memunculkan adanya tindakan tertentu untuk memperbaiki proses belajar mengajar di kelas. Tindakan tersebut dapat berupa pengetahuan. Metode pembelajaran tertentu (Muslich, 2009: 14).Apabila kita cermati pengertian PTK akan sangat jelas bahwa tujuan PTK tidak lain adalah untuk memperbaiki praktis pembelajaran (Subyantoro, 2009: 26) Penelitian tindakan kelas adalah satu strategi pemecahan masalah yang memanfaatkan tindakannyata dan proses perkembangan kemampuan dalam mendeteksi dan memecahkan masalah (Ghony, 2008: 8). Salah satu ciri khas PTK adalah adanya kolaborasi (kerjasama) antara guru dengan peneliti dalam menggali dan mengkaji permasalahan nyata yang dihadapi guru dan atau peserta didik di sekolah (Ghony, 2008: 63).

\section{Pra Siklus}

Tahap prasiklus ini peneliti akan melihat secara langsung dalam proses belajar mengajar khususnya pada pembelajaran Matematika di kelas II SD Katolik Habi. Dalam pelaksanaan pembelajaran pada pra siklus akan diukur dengan indikator penelitian yaitu akan dilihat hasil belajar dari peserta didik. Hal ini dilakukan sebagai dasar untuk membandingkan keberhasilan pembelajaran menggunakan metodethe power of two and four.

\section{Siklus I \\ Perencanaan}

Guru menyampaikan segala sesuatu yang akan dilakukan dalam kegiatan : a) Menyampaikan tujuan pembelajaran; b) Menyampaikan rencana pelaksanaan pelajaran; c) Memberikan pengarahan kepada peserta didik tentang simulasi yang akan dilakukan.

\section{Pelaksanaan Tindakan}

Langkah-langkah dalampelaksanaan tindakan kelas dilakukan sesuaidengan skenario yang telah disusun.Skenario siklus 1 adalah : (a) Peneliti menyiapkan lembar observasi, pendokumentasian, lembar refleksi, dan evaluasi; (b) Peneliti menyiapkan materi bahan ajar yang didiskusikan dalam kelompok; (c) Peneliti memberikan penjelasan kepada peserta didik tentang materi yang akan diajarkan; (d) Guru menjelaskan materi, peneliti bertindak sebagai pengamat; (e) Guru menetapkan salah satu masalah atau pertanyaan yang terkait dengan materi pokok (SKKD atau indikator); (f) Beri kesempatan pada peserta untuk berfikir sejenak tentang pertanyaan yang diberikan oleh guru; (g) Bagikan kertas pada tiap individu peserta didik untuk menuliskan pemecahan masalah atau jawaban (secara mandiri) lalu periksalah hasil kerjanya; (h) Perintahkan peserta didik untuk bekerja berpasangan 2 orang dan berdiskusi tentang jawaban masalah tersebut dan periksalah hasil kerjanya; (i) Peserta didik membuat jawaban baru atas masalah yang disepakati berdua; (j) Selanjutnya perintahkan peserta didikuntuk bekerja berpasangan 


\section{Selestina Vinsensia}

4 orang dan berdiskusi lalu bersepakat mencari jawaban terbaik, lalu periksalah hasil kerjanya; (k) Jawaban bisa ditulis dalam kertas dan guru memeriksa setiap kelompok telah menghasilkan kesepakatan terbaiknya menjawab masalah yang dicari; (l) Guru melakukan penjelasan dan solusi atas permasalahan yang didiskusikan kembali; (m) Guru melakukan kesimpulan, klarifikasi dan tindak lanjut.

\section{Pengamatan / Observasi}

Yaitu prosedur perekaman data mengenai proses dan produk dari implementasi tindakan yang dirancang. Penggunaan instrumen yang telah disiapkan sebelumnya perlu ungkapan secara rinci dan lugas termasuk cara perekamannya (Kunandar, $2010: 129$ ).

\section{Refleksi}

Hasil yang diperoleh pada tahapan observasi dikumpulkan dan dianalisis sehingga diperoleh hasil refleksi kegiatan yang telah dilakukan. Yang dilakukan pada tahap ini adalah memperhatikan kekurangan pada siklus I sehingga dapat diperbaiki pada siklus II.

\section{Siklus 2}

\section{Perencanaan}

Guru menyampaikan segala sesuatu yang akan dilakukan dalam kegiatan : (a) Menyampaikan tujuan pembelajaran; (b) Guru memberikan pertanyaan kepada peserta didik tentang hasil pembelajaran kemarin.

\section{Tindakan}

Langkah-langkah dalam pelaksanaan tindakan kelas dilakukan sesuai dengan skenario yang telah disusun. Skenario siklus II adalah :Sebagaimana siklus I, pada prinsipnya semua kegiatan siklus II mirip dengan kegiatan siklus I, siklus II merupakan perbaikan dari siklus I, di mana : (a) Tahapannya tetap perencanaan, pelaksanaan, pengamatan dan refleksi; (b) Materi pembelajaran berkelanjutan; (c) Diharapkan keaktifan dalam mengerjakan permasalahan yang telah ditentukan sesuai dengan materi pokok; (d) Diakhiri kegiatan atau siklus, guru memberikan tes formatif yang bercirikan kontekstual, sesuai dengan materi pokok yang diberikan; (e) Teknik pengumpulan data meningkatkan keaktifan belajar peserta didik dilihat catatan observasi; (f) Meningkatkan hasil belajar; (g) Teridentifikasi cara yang efektif dalam menerapkan model pembelajaran ThePower of Two and Four model di kelasdilihat dari catatan observasi.

\section{Observasi}

Observasi dilakukan dengan menggunakan lembar observasi. Hampir sama dengan siklus I tetapi lebih menekankan pada hasil belajar dimana perubahan yang lebih diinginkan.

\section{Refleksi}

Refleksi pada siklus II adalah hasil penelitian yang dilakukan dalam kedua siklus tersebut. Jika dari analisis data mengalami peningkatan signifikan, maka penelitian dianggap berhasil. 
Serambi Akademica

Jurnal Pendidikan, Sains, dan Humaniora
Vol. 7, No. 5,

Oktober 2019
pISSN 2337-8085

eISSN 2657- 0998

\section{Teknik Pengumpulan Data}

Observasi

Observasi adalah metode pengumpulan data melalui pengamatan dan pencatatan secara sistematis terhadap fenomena yang diselidiki (Hadi, 2004: 191). Metode ini digunakan untuk memperoleh data tentang situasi belajar mengajar pada saat dilakukannya tindakan.

\section{Dokumentasi}

Dokumentasi berasal dari dokumen, yang artinya barang-barang tertulis. Di dalam melaksanakan metode dokumentasi, peneliti menyelidiki benda-benda tertulis seperti buku-buku, majalah, dokumen, perantara, notulen rapat, catatan harian dan sebagainya. Dokumentasi digunakan untuk mengetahui daftar nama peserta didik, jumlah peserta didik, dan kemampuan peserta didik.

\section{Metode Tes}

Metode tes digunakan untuk mengambil data tentang hasil belajar peserta didik kelas II SD Katolik Habi, dengan indikator : (a) Adanya peningkatan hasil belajar peserta didik pada mata pelajaran Matematika; (b) Peserta didik dapat mencapai ketuntasan nilai kognitif pada mata pelajaran Matematika.

Teknis Analisis Data

Pengumpulan Data

Untuk menganalisis data yang telah terkumpul, dilakukan analisis hasil yang telah dicapai peserta didik dalam tes evaluasi. Data observasi penelitian diberikan dengan pemberian nilai berupa angka yang dikategorikan dengan kurang, cukup, baik, dan sangat baik. Pada tindakan tiap siklus masing-masing satu kali pertemuan kemudian diberi perlakuan kegiatan yang meliputiperencanaan, tindakan, observasi, dan refleksi.

\section{Hasil observasi :}

Untuk mengetahui hasil belajar peserta didik, digunakan daftar nilai kognitif melalui tes evaluasipeserta didik pada akhir pembelajaran siklus. Dari data hasil tes peserta didik pada tiap siklus akan diketahui hasil persentase ketuntasan belajar peserta didik. Selanjutnya dari data tersebut diperoleh pada tiap siklus dianalisis secara deskriptif kualitatif dengan menghitung percentages correction.

Analisis data kuantitatif terdiri atas proses analisis untuk mengetahui tes hasil belajar peserta didik. Untuk mengetahui kemampuan kognitif pesertadidik dalam menyelesaikan soal tesevaluasi, analisisnya dengan cara menghitung rata-rata nilai dan ketuntasan belajar.

\section{Indikator Ketercapaian}

Dalam penelitian ini, peningkatan hasil belajar matematika peserta didik secara optimal ditandai dengan tercapainya ketuntasan belajar tiap individu. Dengan demikian 


\section{Selestina Vinsensia}

yang menjadi tolak ukur keberhasilanpenelitian ini adalah bila secara individu mencapai nilai $\geq 60$, dan ketuntasan klasikal mencapai ketuntasan $75 \%$.

\section{Deskripsi Data \\ Pra Siklus}

Sebelum diadakan tindakan, terlebih dahulu dilaksanakan observasi pembelajaran di kelas II SD Katolik Habi pada hari Senin tanggal 5 Nopember 2018 dengan materi pokok pengukuran waktu. Dari data observasi dan pembelajaran pra siklus, maka diperoleh data hasil belajar peserta didik belum dinyatakan tuntas, karena nilai rata-rata kelas baru mencapai 61,66 dari Kriteria Ketuntasan Minimal (KKM) yang telah ditentukan yaitu 60. Sementara persentase ketuntasan klasikal hanya mencapai 58,33\% jauh di bawah persentase ketuntasan klasikal yangtelah ditentukan yaitu 75,00\%. Sehingga pembelajaran pra siklus perlu dilanjutkan ke siklus I.

\section{Siklus I}

Pembelajaran siklus I ini dilaksanakan karena hasil yang diperoleh pada pembelajaran pra siklus belum mencapai indikator keberhasilan yang ditentukan. Pada hasil belajar pra siklus ranah kognitif nilai rata-rata kelas baru mencapai 61,66 dari Kriteria Ketuntasan Minimal (KKM) yang telah ditentukan yaitu 60. Sementara persentase ketuntasan klasikal hanya mencapai 58,33 \% jauh di bawah persentase ketuntasan klasikal yang telah ditentukan yaitu $75,00 \%$.

Pembelajaran siklus I ini dilaksanakan untuk mengatasi masalah-masalah yang ada pada pra siklus. Pada siklus I ini penelitian dilakukan dengan rencana dan persiapan yang lebih matang dibandingkan dengan pra siklus. Pada siklus inidilakukan perbaikanperbaikan pembelajaran dengan menggunakan metode The Power of Two and Four sebagai upaya untuk meningkatkan hasil belajar peserta didik Kelas II materi pengukuran waktu. Diharapkan dengan meningkatnya hasil tes ini diikuti pula dengan adanya perubahan sikap dan keterampilan peserta didik.

Pembelajaran siklus I dilaksanakan di SD Katolik Habi pada tanggal 12 November 2018 dengan materi pokok pengukuran waktu. Pelaksanaan pembelajaran siklus I diikuti oleh seluruh peserta didik Kelas II yang berjumlah 12 peserta didik. Dari data pembelajaran siklus I, maka diperoleh data hasil belajar peserta didik bahwa hasil belajar siklus I sudah dinyatakan tuntas, karena nilai rata-rata kelas mencapai 72,5 dari Kriteria Ketuntasan Minimal (KKM) yang telah ditentukan yaitu 75,00. Sementara persentase ketuntasan klasikal hanya mencapai $83,33 \%$. Meskipun secara rata-rata dan ketuntasan klasikal sudah dinyatakan tuntas. Tetapi untuk mencapai pembelajaran yang lebih optimal dan penggunaan metode pembelajaran yang lebih baik, maka perlu dilanjutkan pada siklus II.

\section{Siklus II}

Pembelajaran siklus II ini dilaksanakan karena hasil yang diperoleh pada pembelajaran siklus I ingin mendapatkan hasil yang lebih optimal. Pada hasil belajar siklus I sudah dinyatakan tuntas, karena nilai rata-rata kelas mencapai 72,5 dari Kriteria Ketuntasan Minimal (KKM) yang telah ditentukan yaitu 75,00 dan persentase ketuntasan 
klasikalsudah mencapai $83,33 \%$ di atas persentase ketuntasan klasikal yang telah ditentukan yaitu $75,00 \%$.

Pembelajaran siklus II ini dilaksanakan untuk mengatasi masalah-masalah yang ada pada siklus I. Pada siklus II ini penelitian dilakukan dengan rencana dan persiapan yang lebih matang dibandingkan dengan siklus I. Pada siklus ini dilakukan perbaikanperbaikan pembelajaran dengan menggunakan metode The Power of Two and Four sebagai upaya untuk meningkatkan hasil belajar peserta didik Kelas II materi pengukuran waktu. Diharapkan dengan meningkatnya hasil tes ini diikuti pula dengan adanya perubahan sikap dan keterampilan peserta didik.

Pembelajaran siklus II dilaksanakan di SD Katolik Habi pada tanggal 19 Nopember 2018 dengan materi pokok yang sama yaitu pengukuran waktu. Pelaksanaan pembelajaran siklus II diikuti oleh seluruh peserta didik Kelas II yang berjumlah 12 peserta didik. Dari data pembelajaran siklus II diperoleh data hasil belajar peserta didik dapat disimpulkan bahwa hasil belajar siklus II sudah dinyatakan tuntas, karena nilai ratarata kelas mencapai 85 dari Kriteria Ketuntasan Minimal (KKM) yangtelah ditentukan yaitu 75,00 dan persentase ketuntasan klasikal sudah mencapai 91,66\% di atas persentase ketuntasan klasikal yang telah ditentukan yaitu 75,00\%.

\section{Perbandingan Hasil Penelitian Tiap Siklus}

Nilai rata-rata hasil belajar pada pra siklus baru mencapai 61,66 dan persentase ketuntasan klasikal hanya mencapai 58,33\%, naik pada siklus I menjadi 72,5 dan ketuntasan klasikal 83,33\%, naik lagi pada siklus II menjadi 85 dan ketuntasan klasikal menjadi 91,66\%.

Tabel 4. Perbandingan Hasil Belajar Pra Siklus, Siklus I, danSiklus II

\begin{tabular}{|c|c|r|r|l|}
\hline No & Kriteria & \multicolumn{3}{|c|}{ Perbandingan } \\
\hline & & Pra Siklus & \multicolumn{1}{|c|}{ Siklus I } & Siklus II \\
\hline 1 & Rata-rata & 61,66 & 72,5 & 85 \\
\hline 2 & Ketuntasan Klasikal & $58,33 \%$ & $83,33 \%$ & $91,66 \%$ \\
\hline
\end{tabular}

\section{KESIMPULAN}

Berdasarkan hasil analisis dan pembahasan, penelitian ini dapat disimpulkan bahwa keberhasilan proses pelaksanaan pembelajaran melalui metode The Power of Two and Fourdengan menggunakan Penelitian Tindakan Kelas (PTK) dengan menggunakan tahapan perencanaan, pelaksanaan tindakan, pengamatan dan refleksi pada materi pokok pengukuran waktu di kelas II SD Katolik Habi mampu meningkatkan hasil belajar dengan 
Selestina Vinsensia

ditunjukkan adanya perubahan dalam proses pembelajaran yaitu kesiapan dan keaktifan pada saat proses pembelajaran, juga ditunjukkan adanya peningkatan nilai skor tes akhir dari masing-masing siklus dengan rata-rata hasil belajar pada pra siklus mencapai 61,66, siklus I 72,5, dan pada siklus II mencapai 85. Dan ketuntasan klasikal pada pra siklus mencapai 58,33 \%, siklus I adalah 83,33 \% dan mengalami peningkatan pada siklus II dengan ketuntasan 91, 66\%,

\section{DAFTAR PUSTAKA}

Djamarah, Syaiful Bahri Djamarah, 2002, Psikologi Belajar, Jakarta: PT Rineka Cipta Ghony, Junaidy, 2008,Penelitian Tindakan Kelas, Malang: UIN Malang Press

Hadi, Sutrisno, 2004, Metodologi Research II, Yogyakarta: AndiOffset

Kunandar, 2010, Langkah Mudah Penelitian Tindakan Kelas sebagaiPengembangan Profesi Guru, Jakarta : PT. Raja Grafindo Persada.

Muhsetyo, Gatot, dkk., 2008, Materi Pokok Pembelajaran Matematika SD, Jakarta: Universitas Terbuka.

Mansur, S dan Loli. M.P.P. 2019. Upaya Meningkatkan Hasil Belajar Siswa Kelas VII dengan Model Guide Note Taking di SMP San Karlos Habi. Uin Raden Intan Lampung. BIOSFER: Jurnal Tadris Biologi. 10 (1): 21-28. DOI: https://doi.org/10.24042/biosfer.v10i1.3990

Mulyasa E, 2009, Kurikulum yang Disempurnakan PengembanganStandar Kompetensi dan Kompetensi Dasar, Bandung: PT.Remaja Rosdakarya

Muslich, Mas Nur, 2009, Melaksanakan PTK (Penelitian TindakanKelas) Itu Mudah; Classroom Action Research, Jakarta : Bumi Aksara

Mutadi, 2007, Pendekatan Efektif dalam Pembelajaran Matematika, Jakarta: Pusdiklat Tenaga Teknis Keagamaan Depag Bekerjasama dengan Ditbina Widyaiswara LAN-RI

Purwanto, Ngalim, 2000, Prinsip-Prinsip dan Teknik EvaluasiPengajaran, Bandung: PT Rosdakarya

Purwanto, Ngalim, 2000, Psikologi Pendidikan, Bandung: Remaja Rosda Karya.

Slameto, 1995, Belajar dan Faktor-faktor yang Mempengaruhinya, Jakarta :Rineka Cipta.

Subyantoro, 2009, Penelitian Tindakan Kelas, Semarang:Universitas Diponegoro

Sudjana Nana, 2009, Proses-Proses BelajarMengajar,Bandung:Sinar Baru Algesindo

Soedjadi, 2000, Kiat Pendidikan Matematika di Indonesia, Jakarata:Direktorat jendral Pendidikan Tinggi Departemen Pendidikan Nasional 